\title{
ŹRÓDŁA INFORMACJI I INICJATORZY W DZIAŁALNOŚCI INNOWACYJNEJ W GOSPODARSTWACH ROLNICZYCH
}

\author{
Katarzyna Chrobocińska, Katarzyna Łukiewska, Zbigniew Nasalski \\ Katedra Ekonomiki Przedsiębiorstw Uniwersytetu Warmińsko-Mazurskiego w Olsztynie \\ Kierownik katedry: dr hab. Małgorzata Juchniewicz, prof. UWM
}

\begin{abstract}
Słowa kluczowe: innowacje w rolnictwie, źródła informacji o innowacjach, inicjator innowacji Key words: innovations in agriculture, sources of information about innovation, initiator of innovation

S y n o p s i s. W opracowaniu określono najważniejsze źródła informacji o innowacjach oraz inicjatorów działalności innowacyjnej w gospodarstwach rolniczych wykorzystujących w działalności aktywa pochodzące z ZWRSP. Wyniki przeprowadzonych badań wskazują, że inicjatorami działań innowacyjnych byli przede wszystkim właściciele gospodarstw rolniczych. Najczęściej wskazywanymi źródłami informacji o innowacjach byli pracownicy ośrodków doradztwa rolniczego, Internet, a także kursy i szkolenia.
\end{abstract}

\section{WSTEP}

Odniesienie sukcesu w danej branży umożliwia dostęp do tzw. zasobów strategicznych, wyróżniające umiejętności i zdolność ciągłego ich zdobywania, w tym generowanie wiedzy oraz wprowadzanie innowacji. A zatem dzięki kreowaniu i upowszechnianiu nowych rozwiązań można zbudować trwałą przewagę konkurencyjną przedsiębiorstwa, ale innowacje traktuje się także jako jeden z dwunastu filarów konkurencyjności gospodarki. Ponadto innowacje uznaje się za ważny czynnik wpływający na rozwój gospodarczy kraju [Limański 2011].

Działalność innowacyjna w rolnictwie powinna uwzględniać jego specyfikę oraz biologiczny i przestrzenny charakter produkcji. Oznacza to, że należy mieć na uwadze m.in. długie cykle produkcyjne oraz sezonowość produkcji [Kałuża, Rytel 2010]. Innowacje rolnicze definiowane są jako nowe wytwory lub zabiegi produkcyjne, lub też idee, które służą podniesieniu prestiżu społecznego czy wyzwalają działania zespołowe [Maziarz 1977]. Inni badacze akcentują w swoich rozważaniach rolę konsumentów w inicjowaniu i wprowadzaniu nowości, określając innowacje rolnicze celowo wprowadzanymi zmianami przez rolników, które mają zastąpić dotychczasowe sposoby produkcji lub produkty nowymi, bardziej efektywnymi i przydatnymi w danych warunkach [Michałowski, Wiśniewski 2008]. Halina Kałuża i Monika Ginter stwierdziły, że analizując innowacje rolnicze, można dostrzec pewną analogię do podziału innowacji według Podręcznika Oslo Manual 2005 [OECD, EUROSTAT 2005] na produktowe, procesowe, marketingowe i organizacyjne [Kałuża, Ginter 2014]. Ich zdaniem innowacje rolnicze mogą mieć postać działań zwią- 
zanych z upowszechnianiem postępu biologicznego w gospodarstwach, np. wprowadzanie do uprawy nowych, bardziej plennych odmian roślin, odpornych na choroby i niekorzystne warunki przyrodnicze (np. długotrwałe susze). W działalności innowacyjnej w rolnictwie można spotkać się również z nowymi organizacyjnymi rozwiązaniami, np. z tworzeniem się grup producenckich, zmianą kierunku produkcji czy transferem nowych technologii związanych z precyzyjnym nawożeniem i ochroną roślin.

Istnieje wiele czynników warunkujących proces wdrażania innowacji w gospodarstwach rolnych. Są to m.in. czynniki o charakterze społeczno-ekonomicznym, produkcyjnym, finansowym czy związane z postawą rolnika względem innowacji. Bariery innowacyjności mogą pochodzić z otoczenia (np. niepewny popyt, brak lub utrudniony dostęp do zewnętrznych środków finansowych itp.) i z wnętrza przedsiębiorstwa (np. brak środków własnych i możliwości bądź umiejętności w pozyskiwaniu kapitału obcego, brak lub utrudniony dostęp do wiedzy, np. zewnętrznych usług konsultingowych, technologii informatycznych, informacji o rynkach czy brak wyodrębnionych własnych komórek B+R, niechęć bądź strach przed korzystaniem z usług doradczych firm zewnętrznych, problemy z dostępnością usług zewnętrznych itp.) [Jeznach i in. 2016, Janasz, Kozioł 2007, Nieć 2011, Szopik-Depczyńska, Depczyński 2012, Mądra 2013].

W Polsce, podobnie jak w rozwiniętych krajach Zachodu, powstaje system wsparcia innowacyjnych przedsiębiorstw, który tworzą razem instytucje publiczne, uczelnie wyższe, organizacje pozarządowe oraz prywatne firmy. Obecnie do istotnych źródeł pozyskiwania informacji o innowacjach przez przedsiębiorców zalicza się m.in. branżowe i ogólnoinformacyjne serwisy internetowe, tj. np. Portal Innowacji, baza wiedzy o nowych technologiach Ministerstwa Gospodarki, serwis CORDIS, Europe Innova, European Cluster Observatory, InnovationTools, Enterprise Europe Network itp. [www.pi.gov.pl/Firma/chapter_95077. asp]. Pomocna w usprawnieniu transferu wiedzy i wdrażaniu innowacji w rolnictwie może być „Sieć na rzecz innowacji w rolnictwie i na obszarach wiejskich” (SIR), realizowana w ramach działań PROW 2014-2020 [Tabaka 2015].

W procesie dyfuzji innowacji dużą rolę odgrywają źródła informacji o nowościach. Źródłami innowacji określa się czynniki, które inspirują powstanie idei, pomysłów lub projektów, w których konsekwencji poszukuje się i wdraża ulepszenia dotychczasowych rozwiązań oraz nowe pomysły [Janasz, Kozioł 2007]. A zatem proces ten jest inicjowany zazwyczaj w umyśle przedsiębiorcy, gdzie analizuje swoje spostrzeżenia dotyczące wnętrza lub/i otoczenia przedsiębiorstwa. Z kolei sposoby realizacji tych potrzeb mogą pochodzić z wnętrza jednostki lub spoza niej. Jednym ze sposobów umożliwiających realizowanie projektów innowacyjnych jest prowadzenie we własnym zakresie prac badawczo-rozwojowych [Stawasz 1999]. Marek Tomaszewski [2015] zaproponował rozróżnianie pojęć: „źródła innowacji” oraz ,źródła informacji o innowacjach”. Jego zdaniem źródłami innowacji można określić jednostki, które tworzą sposoby zaspokojenia potrzeb innowacyjnych, a dotyczy to rozwiązań technologicznych lub organizacyjnych [Stawasz 2005]. Natomiast do źródeł informacji o innowacjach można zakwalifikować zarówno jednostki, jak i zasoby materialne i niematerialne, które udostępniają informacje na temat innowacji. W tym przypadku udostępnia się informacje o rozwiązaniach technologicznych, z którego sprzedaży źródła innowacji czerpią dochody. Z tego też względu źródła innowacji najczęściej są również źródłami informacji o innowacjach, np. akademickie centra transferu technologii, które tworzone są po to, by przekazywać informacje o innowacjach, a następnie pośredniczyć w sprzedaży wytworzonej przez pracowników danej uczelni technologii na rzecz przedsiębiorców [Matusiak i in. 2005]. Znaczenie źródeł informacji o innowacjach 
jest zróżnicowane w zależności od ich rodzaju. Do najbardziej popularnych zalicza się: klientów, zjazdy, targi, wystawy, literaturę fachową, prospekty, katalogi, prognozy, studia rynku, niezależne placówki badawcze, masowe środki przekazu, prasę i czasopisma, sąsiadów, rodzinę, samego rolnika, doradców i sprzedawców [Oszmiańska 2001]. A zatem ze względu na miejsce powstania źródła innowacji można podzielić na egzogeniczne (np. transfer wiedzy, badania naukowe prowadzone na uczelniach krajowych i zagranicznych itd.) i endogeniczne (m.in. wyniki prac własnego zaplecza badawczo-technicznego, kół jakości, kadry kierowniczej, racjonalizatorów itd.) [Badowska 2012].

Innowacyjność jest motorem zmian, a zmiany są podstawowymi elementami strategii biznesowej. Jednak jest to możliwe, gdy jednostka tworzy kulturę innowacyjności, która powstaje, gdy pracownicy wszystkich szczebli angażują się we wspieranie, promowanie i wdrażanie nowych produktów, usług, modeli biznesowych, świadomie realizują założenia strategii rozwoju innowacyjnego [www.pi.gov.pl/Firma/chapter_95715.asp].

\section{MATERIAŁ I METODYKA}

Realizowanie działalności innowacyjnej w gospodarstwach rolniczych może mieć konkretny efekt w postaci zwiększenia wydajności produkcji, obniżenia kosztów, zwiększenia rynków zbytu i poprawy dochodowości [Świtalski 2005]. A zatem zwiększenie dostępności źródeł informacji o innowacjach, stymulowanie postaw proinnowacyjnych i działań inicjujących tworzenie kultury innowacyjnej, propagowanie rozwiązań innowacyjnych, tworzenie platform wymiany informacji o innowacjach oraz dotyczących możliwości finansowania projektów innowacyjnych przyczyni się zarówno do wzrostu konkurencyjności przedsiębiorstw zajmujących się produkcją rolną, jak i powiązanych z nimi, funkcjonujących w gospodarce żywnościowej. Istotny wydaje się problem dostępności informacji o nowych rozwiązaniach oraz ich wykorzystanie w kształtowaniu postaw innowacyjnych. Celem opracowania była próba identyfikacji przejawów kultury innowacyjności, a w szczególności określenie najczęściej wykorzystywanych w procesie innowacyjnym źródeł informacji oraz inicjatorów działalności innowacyjnej, których gospodarstwa rolnicze uzupełniały potencjał produkcyjny aktywami pochodzącymi z Zasobu Własności Rolnej Skarbu Państwa (ZWRSP).

Badania przeprowadzono w 2016 roku metodą sondażu diagnostycznego za pomocą kwestionariusza ankiety. Dotyczyły one oceny innowacyjności podmiotów użytkujących ZWRSP na terenie województwa warmińsko-mazurskiego. Operat badawczy został dobrany celowo. Była to grupa gospodarstw rolniczych zlokalizowanych administracyjnie w granicach województwa warmińsko-mazurskiego, wykorzystująca w działaniach aktywa pochodzące z ZWRSP. W procesie badawczym uczestniczyło 200 podmiotów, jednak pełne dane zebrano ze 138 gospodarstw (69\% populacji generalnej). Weryfikację ankiet umożliwiła deklaracja respondentów dotycząca wprowadzenia w ostatnich 2 latach innowacji w działalności. Ankieta uwzględniała metryczkę respondentów (wiek i wykształcenie właściciela gospodarstwa, informacje o strukturze produkcji, a także wskazanie ogólnej powierzchni gospodarstwa oraz udział aktywów pochodzących z ZWRSP w całości aktywów badanego gospodarstwa). W kwestionariuszu badawczym skoncentrowano się na najbardziej istotnych kwestiach innowacyjności podmiotów, m.in. zamieszczono pytania dotyczące wprowadzonych rodzajów innowacji, czynników stymulujących oraz ograniczających działalność innowacyjną, a także głównych źródeł informacji o innowacjach wykorzystywanych w gospodarstwach oraz źródeł inspiracji działalności innowacyjnej. 
Realizacja badań była możliwa dzięki współpracy z Oddziałem Terenowym Agencji Nieruchomości Rolnych (ANR) w Olsztynie oraz Warmińsko-Mazurskim Ośrodkiem Doradztwa Rolniczego (ODR) w Olsztynie. Należy dodać, że wyniki badań przedstawione w opracowaniu stanowią część materiału uzyskanego w ramach projektu badawczego sfinansowanego przez Uniwersytet Warmińsko-Mazurski w Olsztynie i ANR Oddział Terenowy w Olsztynie.

Materiał empiryczny pozyskano od 138 respondentów zajmujących się produkcją rolną i użytkujących aktywa pochodzące z ZWRSP. W związku z tym uzyskane wyniki zostały przedstawione dla ww. zbiorowości. Ponadto wyniki badań przedstawiono w podziale na 4 grupy wyodrębnione ze względu na udział aktywów pochodzących z ZWRSP ( $\mathrm{tj}$. do 25,0; 26,0-50,0; 51,0-75,0 oraz powyżej 75,0\% udziału aktywów z ZWRSP w całości majątku badanego gospodarstwa rolnego).

Badana zbiorowość gospodarstw była zróżnicowana. Średnia powierzchnia badanych podmiotów wynosiła 107,5 ha. Najwięcej respondentów posiadało gospodarstwa o powierzchni 51-100 ha (34,1\% wskazań) oraz o powierzchni powyżej 100 ha (28,2\% wskazań). Znacznie mniej badanych rolników deklarowało, że powierzchnia ich gospodarstw wynosi 31-50 ha (21,7\% wskazań) oraz mniej niż 30 ha (16\% wskazań). Większość badanych rolników legitymowała się wykształceniem zasadniczym zawodowym i średnim (78,5\% wskazań), nieco mniej ankietowanych deklarowało wyższe wykształcenie (20\% wskazań), najmniej zaś - wykształcenie podstawowe (1,5\% wskazań). W badanej zbiorowości dominowała grupa rolników w wieku 40-60 lat (56,3\% wskazań). W badaniu także wzięli udział rolnicy w wieku 20-40 lat (36,7\% wskazań) oraz mający ponad 60 lat (7\% wskazań).

\section{WYNIKI BADAŃ}

Istotnym zagadnieniem $\mathrm{w}$ procesie innowacyjnym jest znalezienie inspiracji innowacji, która ma zainicjować planowanie działalności innowacyjnej w przedsiębiorstwie. We współczesnym rolnictwie idea innowacji może pochodzić z otoczenia jednostki, jak również inicjatywa zmian w procesie produkcyjnym może wynikać z doświadczenia $\mathrm{i}$ obserwacji eksperta $\mathrm{w}$ danej dziedzinie. W badaniach respondenci mogli wskazać następujące źródła informacji o innowacjach, tj.: podmioty z otoczenia rolnictwa (np. doradcy z ODR), kursy i szkolenia, Internet, fachową prasę krajową i zagraniczną, targi i wystawy krajowe i zagraniczne, media, kontakty z ekspertami, fachowcami z otoczenia gospodarstwa, konkurencję, współpracę z innymi ośrodkami badawczo-naukowymi, współpracę $\mathrm{z}$ grupami producenckimi.

Uzyskane wyniki badań wskazują, że respondenci planowali innowacje głównie po rozmowach z doradcami z ODR ( $84 \%$ wskazań) oraz po pozyskaniu informacji o działalności innowacyjnej w Internecie (77\% wskazań), ale także na kursach i szkoleniach (66\% wskazań). Warto dodać, że prawie połowa badanych rolników planowała wdrożenie innowacji po przeczytaniu fachowej prasy krajowej (57\% wskazań), uczestniczeniu w targach i wystawach krajowych (52\% wskazań) oraz uzyskaniu informacji w mediach (48\% wskazań). Duża grupa ankietowanych przyznała, że proces innowacyjny rozpoczęła po konsultacjach z fachowcami z otoczenia jednostki (38\% wskazań). Rozwiązania stosowane przez konkurentów jako źródło innowacji wskazało 18\% respondentów, współpracę zaś z ośrodkami naukowo-badawczymi $-12 \%$ ankietowanych. Niewielki odsetek badanych o innowacjach dowiedział się na targach i wystawach zagranicznych ( $8 \%$ wskazań), z fachowej prasy zagranicznej (5\% wskazań) oraz w wyniku współpracy z innymi podmiotami (2\% wskazań). 
Tabela 1. Źródła informacji o innowacjach w badanych gospodarstwach z uwzględnieniem udziału użytkowanych aktywów pochodzących z ZWRSP

\begin{tabular}{lrrrr}
\hline Wyszczególnienie & \multicolumn{4}{c}{$\begin{array}{c}\text { Udział ZWRSP w aktywach } \\
\text { gospodarstwa }\end{array}$} \\
\cline { 2 - 5 } & do $25 \%$ & $26-50 \%$ & $51-75 \%$ & ponad $75 \%$ \\
\cline { 2 - 5 } & \multicolumn{4}{c}{$\%$ wskazań } \\
\hline Podmioty z otoczenia rolnictwa & 76 & 86 & 75 & 86 \\
Internet & 72 & 61 & 50 & 100 \\
Kursy i szkolenia & 7 & 6 & 10 & 71 \\
Targi i wystawy zagraniczne & 61 & 47 & 60 & 14 \\
Fachowa prasa krajowa & 52 & 44 & 75 & 29 \\
Targi i wystawy krajowe & 51 & 47 & 50 & 43 \\
Media & 39 & 31 & 50 & 43 \\
Kontakty z fachowcami z zewnątrz & 18 & 25 & 5 & 43 \\
Rozwiązania stosowane przez konkurentów & 12 & 3 & 15 & 29 \\
Współpraca z ośrodkami naukowo-badawczymi & 1 & - & 5 & 14 \\
Współpraca z innymi producentami w grupie producenckiej & 9 & - & - & - \\
Fachowa prasa zagraniczna & 97 &
\end{tabular}

Źródło: opracowano na podstawie wyników badań własnych.

Z danych zestawionych w tabeli 1. wynika, że najwięcej badanych rolników użytkujących do $25 \%$ aktywów pochodzących z ZWRSP pozyskało informacje o innowacjach z otoczenia (85\% wskazań), z Internetu (76\% wskazań) oraz na kursach i szkoleniach $(72 \%$ wskazań), jak również z fachowej prasy krajowej (61\% wskazań). Połowa respondentów w tej grupie o działalności innowacyjnej innych producentów dowiedziała się z mediów oraz targów i wystaw krajowych. Pozostałe źródła informacji o innowacjach były wskazywane znacznie rzadziej.

Wśród ankietowanych rolników użytkujących 26-50\% aktywów pochodzących z ZWRSP najbardziej popularnymi źródłami informacji o innowacjach były: podmioty z otoczenia rolnictwa (np. doradcy z ODR-u) - 86\% wskazań, Internet - 69\% wskazań oraz kursy i szkolenia - $61 \%$ wskazań. Prawie połowa respondentów z tej grupy uznała, że działalność innowacyjna będzie opisana w fachowej prasie krajowej oraz w mediach. Znacznie mniej badanych rolników wskazało pozostałe źródła informacji o innowacjach.

Wyniki badań dowodzą, że rolnicy użytkujący 51-75\% aktywów pochodzących z ZWRSP najwięcej informacji o innowacjach uzyskali z Internetu (80\% wskazań), od podmiotów z otoczenia (75\% wskazań) oraz z targów i wystaw krajowych (75\% wskazań), a także fachowej prasy krajowej ( $60 \%$ wskazań). Połowa badanych w tej grupie przyznała, że o innowacyjności dowiedzieli się z kursów i szkoleń, mediów oraz ekspertów z otoczenia. Tak jak w poprzedniej grupie, niewielki odsetek uznał, że pozostałe źródła informacji będą pomocne w wprowadzeniu innowacji.

W gospodarstwach, w których użytkowano powyżej 75\% aktywów pochodzących z ZWRSP, stwierdzono, że najwięcej informacji o innowacjach uzyskano z Internetu (100\% wskazań), a także na kursach i szkoleniach oraz od podmiotów z otoczenia gospodarstw (86\% wskazań). Ponadto dobrymi źródłami informacji o innowacjach okazały się targi i wystawy zagraniczne media (71\% wskazań). Mniej ankietowanych o innowacjach dowiedziało się z pozostałych źródeł. 
Proces wprowadzania innowacji został podzielony przez Josepha Schumpetera na etapy, z których pierwszy stanowi pomysł na wynalazek, czyli wytwór wiedzy - inwencja [Schumpeter 1960]. Praktyczne zweryfikowanie i zastosowanie pomysłu umożliwia powstanie innowacji. Wszystkie innowacje zaczynają się od kreatywnych pomysłów. W tym kontekście, termin „kreatywność” jest definiowany jako generowanie pomysłów, innowacją zaś jest implementacja tych pomysłów [Czyż-Gwiazda 2009]. Ale nie tylko pracownik może zainspirować proces innowacyjny w przedsiębiorstwie rolniczym, inicjatorem działalności innowacyjnej może stać się również właściciel gospodarstwa, klienci oraz inni rolnicy. W badaniu respondenci mogli określić, kto najczęściej inicjuje proces innowacyjny w gospodarstwie. Wyniki badań zestawione w tabeli 2 . wskazują, że najczęstszymi inicjatorami wprowadzenia innowacji w badanej zbiorowości ( $3 \mathrm{pkt}$ ) byli głównie właściciele gospodarstw (77\% wskazań). Ponadto respondenci uznali, że w dużym stopniu (2 pkt) działalność innowacyjna była zainspirowana przez: innych rolników

Tabela 2. Inicjator procesu innowacyjnego w badanych gospodarstwach ( 0 oznacza - brak inicjowania procesu, 3 - najczęściej rozpoczyna działalność innowacyjną)

\begin{tabular}{|c|c|c|c|c|}
\hline \multirow[t]{3}{*}{ Wyszczególnienie } & \multicolumn{4}{|c|}{ Liczba punktów } \\
\hline & 0 & 1 & 2 & 3 \\
\hline & \multicolumn{4}{|c|}{ \% wskazań } \\
\hline & \multicolumn{4}{|c|}{ ogółem } \\
\hline Właściciel gospodarstwa & 2 & 1 & 20 & 77 \\
\hline Pracownicy & 77 & 15 & 6 & 2 \\
\hline Klienci & 76 & 11 & 13 & - \\
\hline Inni rolnicy & 53 & 25 & 22 & - \\
\hline \multicolumn{5}{|c|}{ wykorzystujących w działalności do $25 \%$ aktywów pochodzących z ZWRSP } \\
\hline Właściciel gospodarstwa & 3 & 3 & 21 & 70 \\
\hline Pracownicy & 87 & 9 & 3 & - \\
\hline Klienci & 79 & 4 & 13 & - \\
\hline Inni rolnicy & 54 & 24 & 19 & 1 \\
\hline \multicolumn{5}{|c|}{ wykorzystujących w działalności 26-50\% aktywów pochodzących z ZWRSP } \\
\hline Właściciel gospodarstwa & - & - & 19 & 78 \\
\hline Pracownicy & 61 & 17 & 6 & 6 \\
\hline Klienci & 64 & 17 & 11 & - \\
\hline Inni rolnicy & 58 & 25 & 14 & - \\
\hline \multicolumn{5}{|c|}{ wykorzystujących w działalności 51-75\% aktywów pochodzących z ZWRSP } \\
\hline Właściciel gospodarstwa & 5 & - & 15 & 80 \\
\hline Pracownicy & 45 & 20 & 10 & - \\
\hline Klienci & 45 & 15 & 20 & - \\
\hline Inni rolnicy & 30 & 25 & 25 & - \\
\hline \multicolumn{5}{|c|}{ wykorzystujących w działalności powyżej 75\% aktywów pochodzących z ZWRSP } \\
\hline Właściciel gospodarstwa & - & - & - & 100 \\
\hline Pracownicy & 43 & 29 & - & 14 \\
\hline Klienci & 100 & - & - & - \\
\hline Inni rolnicy & 29 & 14 & 43 & - \\
\hline
\end{tabular}

Źródło: opracowano na podstawie wyników badań własnych. 
(22\% wskazań), właścicieli gospodarstw (20\% wskazań), klientów (13\% wskazań) oraz pracowników ( $6 \%$ wskazań). Niewielu respondentów przyznało ( $25 \%$ wskazań), że tylko w niewielkim stopniu (1 pkt) inni rolnicy zainspirowali ich działalność innowacyjną. W opinii większości respondentów, zarówno pracownicy, jak i klienci oraz konkurenci, niewystarczająco inicjowali działalność innowacyjną w badanych gospodarstwach.

Zestawienie wyników uwzględniających pogrupowanie respondentów z uwagi na udział wykorzystywanych w działalności aktywów pochodzących z ZWRSP dowodzi, że występują nieznaczne różnice dotyczące odsetka badanych rolników wskazujących najważniejszych pomysłodawców innowacji w ich działalności. Okazało się, że we wszystkich wyróżnionych grupach z uwagi na udział aktywów pochodzących z ZWRSP najczęstszymi inicjatorami innowacji $\mathrm{w}$ badanej populacji (3 pkt) byli właściciele gospodarstw (70-100\% wskazań), co szczegółowo przedstawiono w tabeli 2. W grupach respondentów wykorzystujących w działalności do 25\% i 26-50\% aktywów z ZWRSP dosyć często (2 pkt) to właściciele inspirowali działalność innowacyjną (odpowiednio 21 i 19\% wskazań). Warto dodać, że ankietowani rolnicy czerpali inspiracje w działalności innowacyjnej także z kontaktów z innymi rolnikami (14-19\% wskazań) oraz z klientami (11-13\% wskazań). Natomiast $\mathrm{w}$ grupach badanych użytkujących ponad 50\% aktywów pochodzących $\mathrm{z}$ ZWRSP często rozpoczynano proces innowacyjny po rozmowach z konkurentami (25$43 \%$ wskazań) i z klientami (20\% wskazań). We wszystkich wyróżnionych grupach ze względu na udział aktywów z ZWRSP uzupełniających potencjał produkcyjny badanych gospodarstw najrzadziej w tworzeniu innowacji ( 0 i 1 pkt) wykorzystano pomysły klientów i pracowników badanych gospodarstw rolnych oraz innych rolników.

\section{PODSUMOWANIE}

Innowacyjność gospodarstw wykorzystujących ZWRSP to problem bardzo istotny w kontekście przyszłości samych podmiotów gospodarczych, ale również w odniesieniu do konkurencyjności agrobiznesu w ujęciu mezo- i makroekonomicznym. Zmieniający się model spożycia żywności determinuje dostosowania w systemach i procesach produkcji oraz dystrybucji żywności. Coraz większego znaczenia nabiera umiejętność wspierania innowacyjności we wszystkich ogniwach sektora rolno-spożywczego. Najtrudniejszą rolę w powstających sieciach innowacji mają najczęściej producenci surowców rolniczych, ponieważ muszą elastycznie dostosować się do zachowań tych ogniw agrobiznesu, które są bliższe bezpośredniemu konsumentowi żywności. Dodatkowo rozproszenie i ograniczona współpraca gospodarstw rolniczych powodują słabą pozycję konkurencyjną rolnictwa w kanałach marketingowych agrobiznesu.

Działania innowacyjne są skuteczne, jeżeli zapewniają przedsiębiorstwu osiągnięcie i utrzymanie właściwego poziomu konkurencyjności, co stanowi niezbędny warunek utrzymania się na rynku. Sukces na rynku może odnieść jedynie ta jednostka, która dostrzeże w otoczeniu szanse i możliwości rozwoju w obecności licznych konkurentów. Identyfikacja wszelkich czynników wspomagających działalność innowacyjną przyczynia się do skonstruowania skutecznej strategii w permanentnie zmieniającym się otoczeniu. Tworzenie kultury innowacyjności, poszukiwanie nowych źródeł inspirujących wdrażanie innowacyjnych rozwiązań, propagowanie i nagradzanie postaw innowacyjnych wydaje się istotne w działalności innowacyjnej, jak również w budowaniu trwałej przewagi konkurencyjnej przedsiębiorstw agrobiznesu. 
Pozytywnie należy ocenić w badanej zbiorowości próby tworzenia kultury innowacyjności, niestety jeszcze nie wszyscy pracownicy w badanych gospodarstwach angażują się na równi $\mathrm{z}$ właścicielami $\mathrm{w}$ inicjowanie i realizowanie działalności innowacyjnej. Warto zauważyć, że respondenci obserwują poczynania swoich konkurentów, co może w przypadkach bardziej przedsiębiorczych jednostek skutkować wykorzystaniem imitacji oraz budowaniem bezpieczniejszej strategii naśladownictwa (doskonale było to widoczne w gospodarstwach wykorzystujących powyżej 51\% aktywów pochodzących z ZWRSP). W badanej zbiorowości w wprowadzaniu innowacji wykorzystywano szerokie spektrum źródeł informacji o działalności innowacyjnej. Najbardziej niedocenianymi źródłami informacji o innowacjach okazały się ośrodki naukowo-badawcze oraz grupy producenckie, a zatem nie dostrzegano możliwości współpracy z ośrodkami naukowo-badawczymi oraz pozytywnych aspektów kooperacji w ramach grup producenckich.

\section{LITERATURA}

Badowska Sylwia, 2012: Źródła i inspiracje wprowadzenia innowacji produktowych, „Zarządzanie i Finanse", R. 10, nr 2, cz. 2, s. 5-23.

Czyż-Gwiazda Ewa, 2009: Kreatywność pracowników stymulatorem wzrostu efektywności organizacji, [w] Kreatywność pracowników stymulatorem wzrostu efektywności organizacji, red. Elżbieta Skrzypek, UMCS, Lublin, s. 371-372.

Janasz Władysław, Katarzyna Kozioł, 2007: Determinanty działalności innowacyjnej przedsiębiorstw, PWE, Warszawa, s. 19-33.

Jeznach Maria, Agnieszka Tul-Krzyszczuk, Jerzy Gębski, Małgorzata Kosicka-Gębska, Krystyna Gutkowska, 2016: Strategie dziatania a bariery rozwoju i innowacyjności małych $i$ średnich przedsiębiorstw przemystu mięsnego i mleczarskiego. 2016. „Roczniki Naukowe Ekonomii i Rolnictwa i Rozwoju Obszarów Wiejskich”, t. 103, z. 4, s. 58-69.

Kałuża Halina, Agnieszka Ginter, 2014: Innowacje w gospodarstwach rolniczych młodych rolników. Agrobiznes. Rozwój agrobiznesu w okresie 10 lat przynależności Polski do Unii Europejskiej, „Prace Naukowe Uniwersytetu Ekonomicznego we Wrocławiu”, nr 361, s. 89-99.

Kałuża Halina, Monika Rytel, 2010: Innowacyjność w świetle studium przypadku gospodarstw rolniczych z gminy Mokobody, „Roczniki Naukowe SERiA”, t. XII, z. 5, s. 68-69.

Limański Andrzej, 2011: Rola innowacyjności w budowaniu przewagi konkurencyjnej przedsiębiorstwa w gospodarce opartej na wiedzy, ,, Nierówności Społeczne a Wzrost Gospodarczy”, z. 23, s. 135-147, https://www.ur.edu.pl/file/15843/012.pdf, dostęp: 29.05.17.

Matusiak Krzysztof B., Małgorzata Matusiak, Paweł Głodek, 2005: Potencjał i kierunki rozwoju centrów transferu technologii, [w] Ośrodki innowacji w Polsce. Analiza krajowych instytucji wspierajacych innowacyjność i transfer technologii, red. K.B. Matusiak, PARP, SOOIPP, Warszawa - Poznań, s. 135-156.

Maziarz Czesław, 1977: Andragogika rolnicza, PWN, Warszawa, s. 165.

Mądra Joanna 2013: Bariery innowacyjności przedsiębiorstw z sektora MŚP, [w] Innowacje w zarządzaniu i inżynierii produkcji, red. Ryszard Knosala, Oficyna Wydawnicza Polskiego Towarzystwa Zarządzania Produkcją, s. 199-208.

Michałowski Kazimierz, Eugeniusz Wiśniewski, 2008: Innowacyjne produkty rolnicze w rejonie północno-wschodniej Polski, [w] Innowacje i innowacyjność w sektorze agrobiznesu, red. M. Adamowicz, Wydawnictwo SGGW, Warszawa, s. 23.

Nieć Melania, 2011: Bariery wprowadzania innowacji w przedsiębiorstwach przetwórstwa spożywczego w Polsce w latach 2002-2010, „Roczniki Nauk Rolniczych, Seria G”, t. 98, z. 4, s. 23-35.

OECD, EUROSTAT, 2005: Oslo Manual, Guidelines for collecting and interpreting innovation data, third edition, Paris.

Oszmiańska Maria, 2001: Wprowadzenie innowacji w indywidualnych gospodarstwach rolnych, http:/www.ppr.pl/wiadomosci/edukacja/wprowadzanie-innowacji-w indywidualnych-gospodarstwach-rolnych-2904, dostęp: 6.04.2017.

Schumpeter Joseph A., 1960: Teoria rozwoju gospodarczego, Warszawa, PWN, s. 104-116. 
Stawasz Edward, 1999: Innowacje a mała firma, Wydawnictwo Uniwersytetu Łódzkiego, Łódź, s. 19-23.

Stawasz Edward, 2005: Źródła innowacji, [w] Innowacje i transfer technologii. Słownik pojęć, red. Krzysztof B. Matusiak, Warszawa, PARP, s. 190.

Szopik-Depczyńska Katarzyna, Radosław Depczyński, 2012: Aktywność innowacyjna sektora małych i średnich przedsiębiorstw (MŚP) w aspekcie konkurencyjności przedsiębiorstw, „Studia i Prace Wydziału Nauk Ekonomicznych i Zarządzania”, nr 25, s. 373-392.

Świtalski Władysław, 2005: Innowacje i konkurencyjność. Wydawnictwo Uniwersytetu Warszawskiego, Warszawa, s. 146-147.

Tabaka Arkadiusz, 2015: Innowacje w rolnictwie i na obszarach wiejskich, http://w-modr.pl/files/ File/wydawnictwa/Ulotki/2015_innowacje.pdf, dostęp: 29.05.2017.

Tomaszewski Marek, 2015: Źródła informacji o innowacjach a kooperacja innowacyjna, „Studia Ekonomiczne. Zeszyty Naukowe Uniwersytetu Ekonomicznego w Katowicach”, nr 214, s. 40-41. http://www.pi.gov.pl/Firma/chapter_95077.asp, dostęp: 6.04.2017.

Katarzyna Chrobocińska, Katarzyna Łukiewska, Zbigniew Nasalski SOURCES OF INFORMATION AND INITIATIVES IN INNOVATIVE ACTIVITIES IN AGRICULTURAL FARMS

\section{Summary}

The study identified the most important sources of information on innovations and the initiators of innovative activity in agricultural holdings using assets from the ZWRSP. The results of the conducted research indicate that the initiators of innovative activities were most often owners of agricultural farms. The most popular sources of information on innovations were agricultural advisory, Internet, courses and training.

Adres do korespondencji:

Dr Katarzyna Chrobocińska, mgr Katarzyna Łukiewska, dr Zbigniew Nasalski Uniwersytet Warmińsko-Mazurski w Olsztynie Wydział Nauk Ekonomicznych, Katedra Ekonomiki Przedsiębiorstw ul. Oczapowskiego 4, 10-719 Olsztyn e-mail: kasiachr@uwm.edu.pl,katarzyna.lukiewska@uwm.edu.pl,zbig@uwm.edu.pl 